\title{
Visitor Satisfaction at UNESCO World Heritage Sites: The Case of the Oasis of Bahla and Land of Frankincense in the Sultanate of Oman
}

\author{
Heba Aziz ${ }^{1,2}$ \\ ${ }^{1}$ Department of Tourism Studies, Faculty of Tourism and Hotels, Alexandria University, Egypt. \\ ${ }^{2}$ Department of Logistics, Tourism, \& Service Management, German University of Technology \\ (GUtech), Halban, Oman
}

\section{Philipp Herzig}

Faculty of Economics, University of Ljubljana, Slovenia

\begin{abstract}
This study aims at contributing to the body of research on visitor satisfaction at UNESCO World Heritage Sites with a case study of the Oasis of Bahla and Land of Frankincense, two Cultural World Heritage Sitesin the Sultanate of Oman. To analyse the level of satisfaction of visitors to the Oasis of Bahla and the Land of Frankincense, a questionnaire was developed which consisted of five main sections in accordance with the research model and in total, 250 visitors took part in the survey. The results showed that the tourists' overall satisfaction for both sites was above average and that visitors would recommend them to other people. The research recommended that UNESCO needs to acknowledge the importance of on-site interpretation and tourism infrastructure for heritage tourists. Also, Omani government needs to develop thought-out management plans and an efficient implementation mechanism in order to enhance the quality of the World Heritage Sites which are attractive for many visitors.
\end{abstract}

Keywords: Visitor Satisfaction, World
Heritage Sites, behavioral intentions, Sultanate of Oman.

\section{Introduction}

Being one of the fastest growing segments of the industry, heritage tourism has become an important aspect of many countrys' tourism strategy (Huh, Uysal, \& McCleary, 2006; Altunel \& Erkut, 2015). It has been recognized as a credible source of economic growth and a tool to erode boundaries between culture, tourism and everyday life (Richards, 1996). The United Nations Educational, Scientific and Cultural Organization (UNESCO) has made it their core goal to protect and preserve heritage sites of outstanding universal value all around the world. These World Heritage Sites (WHSs) take a special place in heritage tourism since a designation usually is considered as branding (Timothy, 2011) which makes it more visible to potential visitors. Tourists often associate the World Heritage status with certain attributes which include a good level of management as well as a fair amount of on-site interpretation that 
communicates the universal value of the place (Poria, Reichel \& Cohen, 2013).

Although previous research conducted by various authors (e.g. Williams 2005; Yan \& Morrison 2005; Poria et al., 2013) has dealt with visitation to WHSs in connection to experience and satisfaction, only very few utilized the approach of comparing the actual experience of the visitor with the overall satisfaction and resulting behavioural intention. Especially when specific attributes of the destination are taken into consideration which is in parts coined to WHS, research is lacking behind. As stated by Chen and Chen (2010), also in tourism context, satisfaction is primarily measured as a function of pre-travel expectations and post-travel experiences. This method has been introduced by Oliver (1980) and reached broad adoption. However, in many cases WHSs in countries that are not considered well-established tourism destinations; visitors do not have certain expectations and therefore, cannot compare them to their post-evaluation of the visit. Churchill and Surprentant (1982), Tse and Wilton (1988) and Dabholkar, Shepherd and Thorpe (2000) take a similar approach and pledge for neglecting expecations and only contrast experience and satisfaction. As mentioned above, this study will not only analyze the relationship between overall experience and satisfaction but also whether certain dimensions and attributes are especially influencing the satisfaction of the visitor. Facilities and employees, physical appearance, accessibility and interpretation consisting of several attributes are hereby taken into consideration. Besides acknowledgement of demographics and travel patterns of visitors to the chosen WHS which backs the research on differences between general heritage tourists and visitors to WHSs (Adie \& Hall, 2016), the assessment of whether the outstanding universal value which is the crucial factor of a WHS designation is communicated to and understood by the visitors as well as how important the factor is that the site has a UNESCO label. This research composition can support management decisions with the goal of increasing visitor satisfaction and comply with the spirit a UNESCO World Heritage designation testifies for. In order to contribute to the rather small body of research that has been done on this issue and generally on visitors at UNESCO WHSs (Bloemer \& de Ruyter, 1998; Zeithaml, 2000; Adie \& Hall, 2016), this study aims at investigating the relationship between the visitation experience, overall satisfaction and behavioural intention as well as general and more specific factors of satisfaction of visitors at two WHSs in the Sultanate of Oman.

\section{Literature Review}

\subsection{Supply Side: Heritage Tourism}

The terms cultural and heritage tourism are equipped with a broad variety of definitions. In its convention concerning the protection of the World Cultural and Natural Heritage, UNESCO defines cultural heritage in a broad sense including monuments, groups of buildings and sites which in detail can be "works of man or the combined works of nature and man, and areas including archaeological sites which are of outstanding universal value from the historical, aesthetic, ethnological or anthropological point of view" (UNESCO, 1972). This broad definition is useful in order to "encompass not only major historic sites and institutions but the entire landscape of the region with its geographic base (Bowes 1989, p. 36). 13 years later the UNWTO describes cultural heritage in connection to tourism as the movement of persons due to cultural motivations such as study tours, performing arts, travel to festivals 
and other cultural events, visit to sites and monuments, travel to study nature, folklore, or art or pilgrimages (UNWTO 1985). Following this definition but defining cultural tourism as the umbrella term, Richards (1997) states that cultural tourism includes all movements of persons to specific cultural attractions such as heritage sites, artistically and cultural manifestations, and arts and drama outside their normal place of residence. However, Prentice (1993) describes heritage as not only landscapes, natural history, buildings, artifacts, and cultural traditions which are passed on from generation to generation but every aspect that can be promoted as tourism products. He also differentiates between types of heritage, namely built, natural and cultural heritage.

The tourism industry is growing at a vast speed and has been titled the world's largest industry since the mid-1980s (Timothy \& Boyd, 2003). Cultural and heritage tourism has become the most prosperous segment within the industry (Huh et al., 2006; Altunel \& Erkut, 2015) and the United Nations World Tourism Organization (UNWTO) acknowledged that heritage tourism has gained high importance for many travelers. Almost $40 \%$ of international trips include culture and heritage as part of the experience (Timothy \& Boyd, 2003) which hardly makes heritage a niche of tourism.

Several authors have analyzed the relationship between heritage and tourism in their publications (Ashworth, 2000; Timothy \& Boyd, 2003; Ho \& du Cros, 2005). Ashworth (2000) proposes three main schools of thought labelling them automatically harmonious, inevitably in conflict, and potentially sustainable. Furthermore, a framework has been introduced by McKercher, Ho \& du Cros (2005) due to the assumption that the relationship between heritage and tourism is intricate owed to its dynamic nature. Seven possible relationships in connection to different stages of the heritage tourism lifecycle have been identified and include denial, unrealistic expectation, parallel existence, conflict, imposed co-management, partnership, and cross purpose (Zhang \& Zheng, 2014). Denial describes an early stage and can result in not-used cultural heritage asset, parallel existence of heritage and tourism or conflict between the two. Unrealistic expectation can be caused by people in charge of the supply side, for example the site manager. A parallel existence is possible when roles don't overlap, and conflicts arise when uncontrolled tourism threatens the 'survival' of the heritage product. Imposed co-management can occur after a conflict situation and means imposing artificial solutions to end the dispute between stakeholders which might jeopardize the cultural integrity (McKercher et al., 2005). Sincere partnerships are rare but can be established when the common goal of providing a satisfying experience to the visitor is agreed upon. When using tourism to justify the use of for example ancient buildings, intangible heritage attributes might be lost. This type of relationship is referred to as cross purposes relationship and emphasizes the need of finding a balance between conservation and the use of heritage sites for tourism (Garrod \& Fyall, 2000).

\subsection{Demand Side: Heritage Tourists}

Timothy and Boyd (2003) describe that scholars define heritage in either a supply-led or demand-led manner whereas a significant part of heritage tourism literature has focused on the supply side (e.g. Smith, 1988; Wigle, 1994). However, it is important to emblaze the continuously growing demand for vacation with more cultural elements and authentic experiences as opposed to exclusively 
regenerative holidays (Ritchie and Inkari, 2006; Yankholmes and Akyeampong, 2010). Especially a transitional phase from the product-led to a more visitor-orientated development that focuses on preferences and experience quality of the tourist (Apostolakis \& Jaffry, 2005) must be acknowledged. Several studies segmenting and analyzing the profile of cultural tourists exist but only few that explicitly focus on visitors to heritage destinations, especially to UNESCO WHSs (Ramires, Brandão \& Sousa, 2016). In general, demand can be differentiated in current, latent or unmet and option demand as introduced by Weisbrod in 1965. Current demand is the part of a population that is able or willing to actually participate in tourism. The second category describes the difference between the current demand and the entire potential of participation while option demand is defined as the amount a person is willing to pay for the option of consuming the product in the future. Also, demand for heritage tourism is less elastic and shows less seasonal variation. The listed categories apply for tourism as a whole but also for heritage tourism with the difference that it is directed to heritage tourists (Timothy \& Boyd, 2003). When aiming to segment heritage tourists it is necessary to distinguish heritage tourists from tourists at heritage places (Poria, Butler \& Airey, 2003). According to the authors, heritage tourists are interested in the heritage attributes of the site whereas tourists at heritage places may not be aware of the cultural value of the site but potentially are attracted by other attributes onsite.

Understanding heritage tourism as one of the fastest growing segments within tourism itself (Chen, 1998) leads to the need of segmenting it into subcategories in order to gain knowledge on the dimensions that are of interest for the tourist (Huh et al., 2006).
Although heritage tourism represents a certain aspect of the global phenomenon of tourism, distinct sub-segments are important to acknowledge and target directly. Kerstetter, Cofer and Graefe (2001) see segmentation as necessary to create programs and promotional campaigns. Finding out about benefits that visitors seek when visiting heritage destinations was the aim of a study conducted through mailing list by Weaver, Kaufman and Yoon (2002) that resulted in the identification of three dimensions ("Escape", "Social" and "Education") and two clusters: "Active Benefit Seekers" and "Loners". A similar segmentation has been introduced by Timothy and Boyd (2003) who identified passive and serious heritage tourists. Passive heritage tourists who do not visit heritage sites as a predominantly goal but include it in their trip when passing by or when estimating the historic value as sufficient. They show characteristics of mass tourism and do not have the same motivations as serious heritage tourists. This group is passionate about heritage and visiting heritage sites most probably is the purpose of their travel. Align with the approach of segmenting heritage tourists by their level of seriousness, McKercher (2002) identified five segments of heritage tourists in Hong Kong. Dependent on the importance of cultural motives titled as "centrality" and the depth of the experience, he suggests categorizing heritage tourists into "the purposeful" who is characterized by high centrality and depth, "the sightseeing" (high centrality but shallow experience), "the casual" (modest centrality and shallow experience), "the incidental" (low centrality and shallow experience) and lastly "the serendipitous" with low centrality but deep experience. 


\subsection{Tourism at UNESCO WHSs.}

A special case is World Heritage tourism and refers to heritage sites that are inscribed in the WHL initiated by UNESCO. It can be understood as a brand segment of general heritage tourism (Hall \& Piggin 2003). According to Timothy and Nyaupane (2009), many countries try to improve the visibility of their heritage sites with aspiring to have them designated the World Heritage status. A designation usually is perceived as branding (Timothy 2011) or labelling (Yang, Lin \& Han 2010) and according to Yang (2014, p. 74), UNESCO is a powerful but debatable factor and some destinations do not promote it as aggressively as others. However, also for WHSs it is essential to segment their tourists in order to find the right strategy in terms of visitor experience, revenue generation and preservation (Hall \& McArthur 1993). The Organisation for Economic Co-operation and Development or OECD (2009) identifies the too general marketing of heritage sites as a core problem for tourism destinations since cultural tourists seek specific experiences and not a large variety of products. This factor comes particularly into play for a World Heritage Site due to its classification under the purview of a unified brand (Hall \& Piggin, 2003) although the attributes and experiences of WHS vary from destination to destination. Adie and Hall (2016) observed that only very few authors have intended to analyze the segment of World Cultural Heritage tourists although $77.4 \%$ of the properties inscribed in the WHL are cultural. Palau-Saumell et al. (2013) agree with this view only listing two other studies examining consumer behaviour at WHS (Poria, Reichel \& Cohen 2011) and the influence of the WHS brand on tourists' motivation for visiting WHS (Marcotte \& Bordeau, 2006).
In terms of demographics, literature with the topic of World Heritage tourism demonstrates similar results in comparison with studies of general heritage tourism. The Australian case study from King and Prideaux (2010) showed that the number of women visiting WHS was marginally higher than the one of men. The same observation was made by Wang et al. (2015) for Kanas in China and also Remoaldo, Ribeiro, Vareiro and Santos (2014) noted more female than male visitors to the World Heritage City of Guimaraes, Portugal. Adie and Hall (2016) determined only marginal differences between the number of women and men visiting the considered WHSs. In terms of education the findings were equal for all three studies showing consistently high education of World Heritage tourists what verifies and goes align with the findings for the general phenomenon of heritage tourism from the literature mentioned before. However, one significant difference was found in terms of scale. Huh et al. (2006) noted that heritage tourists most commonly are from the surrounding area and therefore domestic, World Heritage visitors however appear to be in many cases of international nature. In their exploratory study, Poria, Reichel and Cohen (2013, p. 273) bring up the point of associations heritage tourists have when confronted with World Heritage. Participants linked the label to being a culturally famous site of major significance to humankind meaning that a designated site has to be of value for the entire human race and not only for a specific group of people. Also, the findings let conclude that WHSs are declared as national tourist highlights that must be visited. Interestingly enough however, none of the participants recognized the World Heritage Site logo. Also, low awareness was discovered in terms of what the designation of a site as World Heritage represents (Williams, 2005) and Yan and Morrison (2007) did not find a 
strong relationship between awareness of the fact that a site is labelled World Heritage and the decision to visit it. Aligned with these studies, Hall and Piggin (2001) found out that stakeholders often expected a higher increase in visitor numbers than reached and eventually, Poria et al. (2013) come to the conclusion that the designation does not have a remarkable impact on tourism demand. In contrast, Shackley (1998) illustrates the enrolment of a World Heritage Site as virtually a guarantee of a visitor number increase, due to its international visibility. Also, Bianchi (2002) recognizes a WHS designation as an indicator of quality for international markets. Significant impact on tourist flows and types of visitors has been detected by Ramires et al. (2016) in a study conducted in the World Heritage City of Port, Portugal. Its international image as an attractive tourism destination had been strengthened through the UNESCO label. Adie and Hall (2016) state World Heritage designations seem to be particularly attractive for European tourists with German, English and French visitors on the forefront. Statistics show that $60 \%$ of European tourists are seeking cultural aspects and $30 \%$ of destinations were chosen by the offer of heritage sites (Remoaldo et al., 2014). Although the official intention of a listing is to protect global heritage for future generations, the debate between heritage protection and tourism development is ongoing (PalauSaumell et al., 2013).

\subsection{UNESCO WHSs in Oman}

The Sultanate of Oman accepted the Convention Concerning the Protection of the World Cultural and Natural Heritage on Tuesday 6th of October 1981. As mentioned before, four cultural sites are inscribed in the WHL after the Arabian Oryx Sanctuary lost its status in 2007. For the purpose of this study, two of the sites have been chosen due to their level of touristic development. These two sites are Oasis of Bahla and Land of Frankincense. The Archaeological Sites of Bat, Al-Khutm and Al-Ayn and Aflaj Irrigation Systems of Oman are also sites of Outstanding Universal Value but are not under management for touristic purposes yet although it is possible to visit them.

\subsection{Oasis of Bahla}

After 20 years of restoration, Bahla Fort which is located in the Al Dakhiliya region opened its gates to the public in 2012. Due to its poor condition during this period and discussion on how the work was done, it was moved to the List of WHSs in Danger in 1988, only one year after the Oasis of Bahla of which the fort is part was awarded the World Heritage status. After consultation with experts from UNESCO and a management plan "for the Bahla Fort and Oasis settlement in Oman to protect the area from further degradation" (Atkins n.D.) it was developed by Atkins consultancy firm, the site regained its former status in 2004.

The Oasis of Bahla includes Bahla Fort with the adjacent Friday Mosque but also the surrounding mud-brick settlement and palm grove. According to UNESCO (n.D.-a), the oasis owes its prosperity to the Banu Nebhan tribe which was the dominant group in the area from $12^{\text {th }}$ to end of the $15^{\text {th }}$ century. The Bahla Fort is a significant example for the technique of using unbaked bricks and stone foundations and emphasizes the power of the tribe at that time who dominated the central Omani region and made Bahla their capital. The fort consists of an extensive wall with multiple watchtowers and gateways which make it a labyrinth of mud brick dwellings. Parts of the Aflaj Irrigation System which also is inscribed in the WHL as a separate site was used to manage the watering of the oasis. Furthermore, the souq (traditional market) which was 
located within easy surveillance from the fort was is included in the UNESCO site.

\subsection{Land of Frankincense.}

The World Heritage Site that was inscribed in the WHL as Land of Frankincense in the year 2000 is located in the Dhofar region and consists of four components. Together they are a testimony of the civilizations of south Arabia and the trade of frankincense which is considered to be one of the most important luxury items in antiquity transported and sold from the Mediterranean and Red sea regions to Mesopotamia, India and China.

"The Land of Frankincense sites include all elements necessary to express its Outstanding Universal value" (UNESCO n.d.-b). Criterion iii is complied with through importance of the frankincense trade in the antiquity and the Oasis of Shisr as well as Khor Rori and AlBaleed are significant examples medieval fortified settlements which fulfills requirements of criterion iv. Furthermore, the size of the sites is sufficient and represent all features which are important to indicate significance. Attributes are in good condition and functions are fully maintained. Development has not affected the properties and no threats are observed by UNESCO due to its appropriate protection by the government with the Royal Decree No. 6/80 and Royal Decree No. 16/2001. Additionally, buffer zones and fencing requirements have been respected. These factors together with the fact that the archaeological sites had no inhabitants in centuries lead to the conclusion that "the authenticity of the property is not open to questions" (UNESCO n.D.-b). A management plan is in place which has led to further protection of the sites against interventions by visitors for example by access paths that have introduced. A visitor interpretation center is available in Khor Rori and Al-Baleed respectively to manage the number of visitors and give historical information. A similar facility is currently planned for the Oasis of Shisr which is part of the strategy "to inform regional, interregional and international visitors about the rich tradition of the Land of Frankincense" (UNESCO n.D.-b).

\subsection{Visitors Satisfaction with UNESCO WHSs}

\section{- Expectations and satisfaction versus experience and satisfaction}

Generally, expectations are defined as performance of establishment, ideal performance or desired performance (Teas 1994, p. 134). According to Oliver (1980) expectations are influenced by the product itself including one's prior experience, the context in which the possibility to purchase the product was communicated (e.g. salespeople) and individual characteristics of the consumer (e.g. persuasibility or personal distortion). As already mentioned, Oliver's approach to measuring satisfaction has been adopted by many researchers in the field of service quality (Babakus \& Boller, 1992; Lewis \& Booms, 1983; Parasuraman, Zeithaml \& Berry, 1988). The expectancy-disconfirmation paradigm assesses satisfaction by relating the perceived quality to initial expectations against which it is either confirmed when meeting the expectations, negatively disconfirmed if the customer is disappointed or positively disconfirmed when expectations have been exceeded (Baker \& Crompton, 2000). Oliver defines satisfaction as "a function of an initial standard and some perceived discrepancy from the initial reference point" and states that "satisfaction soon decays into one's overall attitude toward purchasing products" (1980, p. 460). Chon and Olsen (1991) discovered a solid correlation between tourists' expectations and their satisfaction with the destination and also Pizam and Milman (1993) provided 
research with the result of disconfirmations being relatively good predictors of overall satisfaction.

To understand what makes an experience valuable, Otto and Ritchie (1996) developed an experience quality scale with the factors hedonics (affective responses), peace of mind (physical and psychological safety), involvement (being able to choose and control offers) and recognition as in the sense of feeling important to the service providers. Kao, Huang and Wu (2008) followed this example for a study on theme parks and likewise conceived experiential quality by four factors. Immersion relates to involvement which lets the consumer to perceive time as passing quickly while surprise refers to the uniqueness of the offer. Participation touches upon the interaction between consumer and the product and fun simply implies happiness and enjoyment. In addition, Kao, Huang and $\mathrm{Wu}$ were able to establish the result of a positive relationship between the experiential quality and satisfaction which furthermore influences behavioural intentions positively (Chen \& Chen, 2010) which was again confirmed by Yang and Lin (2014) for WHSs. Therfore, the first hypothesis for this study can be formulated as follows:

H1: There is a positive and significant relationship between "Experience Quality" and "Satisfaction"

To get a sufficient knowledge of the tourists' behaviour and their satisfaction towards the destination or a set of attributes is essential for managers to promoting the destination (Yoon \& Uysal, 2005). The critical role of attribute performance in determining satisfaction has received wide attention in various studies (Pizam et al., 1978; Kozak \& Rimmington, 2000; Chi \& Qu, 2008; Meng, Tepanon \& Uysal, 2008). Churchill and Surprenant (1982) agreed with this opinion and stated that quality can be measured in terms of attribute performance. In their study on a resort destination, Meng et al. (2008) noted that the most important indicator for satisfaction was the evaluation of attribute performance. Furthermore, Chi and $\mathrm{Qu}$ concluded that "it can be said that tourists' overall satisfaction was determined by destination image and attribute satisfaction" (2008, p. 632).

Significant variance in number and nature of attributes that are considered relevant for sparking satisfaction among tourists at destinations can be found in literature of the tourism field (Dorfman, 1979; Pearce, 1982). Attribute satisfaction is "the consumer's subjective judgment resulting from observations of attribute performance and information satisfaction the "subjective satisfaction judgment of the information used in choosing a product" (Spreng et al. 1996, p. $17 \& 18)$. A variety of researchers have found that it is important to measure satisfaction with each of the attributes because (dis)satisfaction with one of them leads to (dis)satisfaction overall (Pizam et al., 1978; Rust, Zahorik \& Keininghan, 1996; Kozak \& Rimmington, 2000). In consideration of these findings and in the context of heritage tourism, it is essential that the presentation of the heritage product stimulates the interest and involvement of the visitor. De Rojas and Camarero (2008) list location, internal distribution, walkways, lighting and informative panels as examples. According to Trinh \& Ryan, tourists are becoming more and more concerned with "not just being there, but with participating, learning and experiencing the 'there' they visit" (2013, p. 241) and Poria et al., (2009) highlight the importance of acknowledging interpretation as a key factor of the overall experience. 
Attributes with high influence of satisfaction are specific elements of tourism supply such as gastronomy, accommodation, culture and entertainment and hospitality (Ramires et al., 2016) whereas others are more generic (Kozak \& Rimmington, 2000). These specific attributes of tourism supply have been recognized as important to tourists in large parts and should be paid special attention to. As Pavesi, Gartner and Guillet (2015) as well as Ramires et al. (2016) argue, also other attributes going beyond the supply of culture and heritage such as mobility, accessibility, cleanliness and safety as well as hospitality are well-worth highlighting as important satisfaction factors (Ramires et al., 2016). Timothy and Boyd (2003) emphasize that establishing shopping facilities creates motivation for tourists to spend money and can act as a main contributor to revenues at heritage sites. On the Isle of Man, Prentice (1993) observed that meals, snacks and gifts summed up into one-fifth of tourists' expenditure and although it is important to not disturb the heritage aspect, Timothy and Boyd (2003) confirm this discovery and state that shopping makes up $20-50 \%$ of total on-site expenditure and hence is one of the main activities that tourists undertake when travelling. Furthermore, a positive shopping experience can also add to an increase of overall satisfaction. What has to be noted is that all the discussed attributes fall in the category of controllable elements. Uncontrollable attributes such as scenery and weather are not taken into consideration since taking influence is not possible even if they lead to dissatisfaction (Kozak \& Rimmington, 2000). In the study on the historic city of Melaka in Malaysia which was designated a UNESCO World Heritage Site in 2008, it was that due to the constant arrival of tourists, infrastructure played a crucial role in order to make the site attractive for tourists (Jusoh et al., 2013). In the context of the Alta Museum in Norway which is associated with a UNESCO World Heritage Site, Johanson and Olsen (2010) noted that location is an important attribute and that visitors spent more time on activities such as relaxing in the café and browsing through the gift shop than looking at the exhibits. Furthermore, Poria, Reichel and Cohen (2013) concluded that visitors do not require a site to be attributed as antique but rather significant to human culture.

Based on above discussed literature, the following hypotheses are formulated:

Hla: There is a positive and significant relationship between the dimension "Facilities and employees" and overall "Satisfaction"

H1b: There is a positive and significant relationship between the dimension "Physical appearance and maintenance" and overall "Satisfaction"

H1c: There is a positive and significant relationship between the dimension "Accessibility" and overall "Satisfaction"

Hld: There is a positive and significant relationship between the dimension "Interpretation" and overall "Satisfaction"

Something most studies with the topic of customer satisfaction have in common, regardless of which theory was followed, is the recognized relationship between the experience, satisfaction and behavioural intention (e.g. Olsen, 2002; Chen \& Tsai, 2007; Chen \& Chen, 2010; Palau-Saumell et al., 2013). Palau-Saumell et al. (2013) demonstrated in their study that influence of satisfaction towards tourists' behavioural intentions exist, similar to Baker and Crompton (2000) who state that a direct 
relationship between the quality of the experience and user satisfaction often has been found when included in the model (e.g. Churchill \& Surprenant, 1982; Tse \& Wilton, 1988). Furthermore, the authors concluded that satisfaction is a useful predictor of the behavioural intentions. Accordingly, we formulated the following hypothesis:

H2: There is a positive and significant relationship between "Satisfaction" and Behavioural Intention

To acknowledge that heritage sites are unique and that naturally, different results can be achieved for each of the WHSs which are part of this study, hypotheses are introduced that refer to significant differences between them. The relationships of $\mathrm{H} 1$ and $\mathrm{H} 2$ will be tested for each site respectively:

H3: There is a significant difference in "Experience Quality" between the analysed UNESCO sites

H3a: There is a significant difference in "Satisfaction" between the analysed UNESCO sites

H3b: There is a significant difference in "Behavioural Intention" between the analysed UNESCO sites

Due to the intention of this study to give insight on other factors that can have an influence on customer satisfaction, additional hypotheses are introduced that have not been widely discussed in previous literature. However, they connect to the general discussion of heritage tourists and their travel behaviour. $\mathrm{H} 4$ and $\mathrm{H} 4 \mathrm{a}$ are used to find out whether satisfaction is influenced by the way the visitor shapes his stay at the site.
H4: Visitors who spent more money on-site were significantly more satisfied with their visit

H4a: Visitors who spent more time on-site were significantly more satisfied with their visit

Furthermore, analysis is conducted to identify if satisfaction decreases when the UNESCO label is the main reason to visit the site due to specific attributes that might be demanded and connected with the designation. Correspondingly, it is also tested whether the level of satisfaction is influenced when visitors already have experienced other UNESCO sites on the globe

H4b: Visitors whose main reason to visit the site was the UNESCO label were significantly less satisfied with their visit

H4c: Visitors who have visited other UNESCO sites before were significantly less satisfied with their visit

At last, hypotheses five and six are proposed to gain knowledge on how spending on-site can be increased. For managerial purposes, the relationship between the duration of the visit and the amount of money that was spent onsite. Additionally, it is tested whether the travel type (cruise, travel package, selforganized, business or other) influences the spending behaviour of the tourist while visiting the World Heritage Site. In that effect, two more hypotheses are tested for the purpose of this study:

H5: There is a significant relationship between the time and money spent on-site

H6: There is a significant relationship between the nature of the visitor's trip and the money spent 


\section{Conceptual model of the study.}

Considering the discussion of the relationships and differences between expectations, experiences and satisfaction and the models presented, a conceptual model for the study of tourist satisfaction at two UNESCO WHSs in Oman is proposed (See Figure 1).

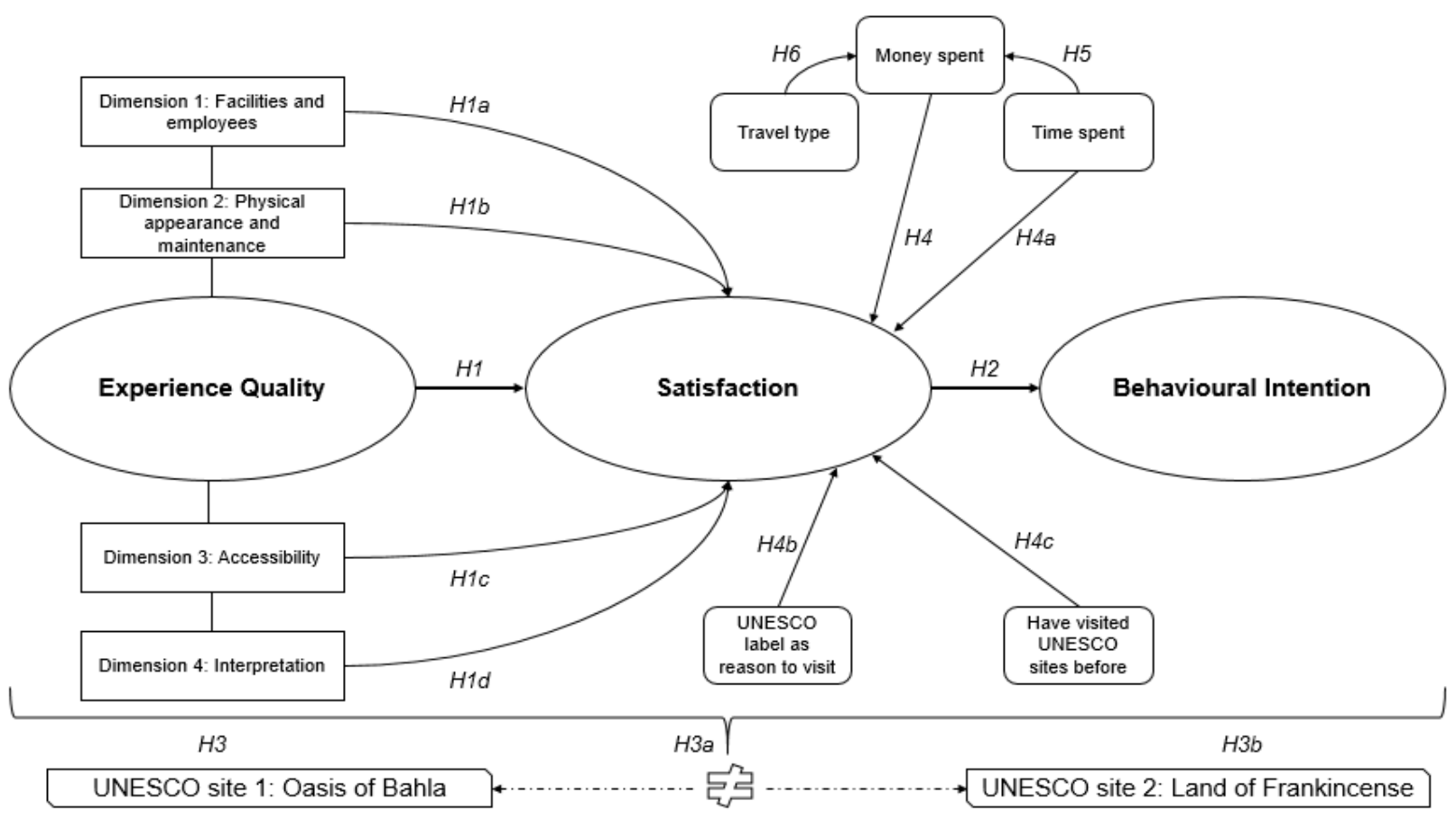

Figure 1: Conceptual Model.

\section{Methodology}

In order to achieve the objective of gaining information on visitor satisfaction at UNESCO sites in Oman, data have been gathered through the distribution of questionnaires. Results have been analysed to test and confirm or disconfirm previous hypotheses. The heritage sites chosen for the conduction of the cross-sectional study had to fulfil three main criteria: (i) to be designated a UNESCO World Heritage Site, (ii) made accessible to the general public with clear entrances and exits and therefore open for tourism and (iii) be under management what implies that employees are on-site which was crucial for the distribution of the questionnaires. Four UNESCO sites exist in the Sultanate of Oman but only two of them met all requirements: the
Oasis of Bahla in the Dakhiliya Governorate, approximately 200 kilometres from the capital Muscat and the Land of Frankincense, a UNESCO site located in the south of the country in Dhofar Governorate. Here, the study has been conducted at the archaeological site of Al-Baleed with the associated on-site museum. Al-Baleed has been considered the best option to reach as many visitors as possible due to the fact that a clear entrance and exit exist and a large number of tourist groups will visit this place. However, for the purpose of the study, the official name Land of Frankincense has been used which includes also the other sites namely Wadi Dawkah, the Caravan Oasis of Shisr, the port of Khor Rori and Al Baleed. 
Oasis of Bahla and Land of Frankincense qualified as study objects since they were awarded the UNESCO label and are managed as a touristic attraction.

Since the aim of the study was to measure visitor satisfaction at Omani UNESCO sites, the target population was not restricted to tourists but included Omani residents as well. The recruitment of voluntary participants of this target group was carried out randomly, hence a convenience sample was gathered without a designation of visitors to certain groups (e.g. test group). The participants were informed that the survey was anonymous, and results would be used for research purposes only. Respondents had to be at least 18 years of age and no incentive apart from the academic contribution that was supported by the visitor's participation was given.

To test the six hypotheses derived from the literature review, a questionnaire was developed consisting of five main sections. These sections include general "Demographic information", "Travel pattern and further information", "Experience Quality", "Satisfaction" and "Behavioural Intention". The latter three sections ("Experience Quality", "Satisfaction" and "Behavioural Intention") are the variables used in the study. To ensure validity and reliability, sections, items and attributes were generated in accordance with the reviewed literature and adapted for the purpose of this study. A 5point Likert-scale was applied for the study which has widely been used in similar research on customer and visitor satisfaction (e.g. De Rojas \& Camarero, 2008; Trinh \& Ryan, 2013; Vareiro et al., 2015; Wang et al., 2015; Palau-Saumell et al., 2015) and ranged from "Strongly disagree" to "Strongly agree". Here, the option "Not applicable" was given and explained to be chosen if the assessed attribute has not been encountered or was simply not existent on-site.

Participants of the study were asked to evaluate their experience at the World Heritage Site based on a pool of 20 destination attributes. As mentioned before, these attributes were clustered into four dimensions which were not stated on the questionnaire but used for the purpose of analysis. As described by Timothy and Boyd (2003), facilities (e.g. toilets, visitor center etc.) play a major role in tourism and hence were included for the survey. Furthermore, the visitor was asked to state his or her level of agreement with statements referring to the contact with the employees and the local community. Cleanliness, safety and entertainment factor for children were part of the second dimensions while the third evaluated the experience of travelling to the site. Both dimensions have been considered important by several authors (e.g. Ramires, 2016; Jusoh et al., 2013) and therefore were added to this study. The fourth dimension which was included for the evaluation of the experience quality targeted the perception of visitors regarding the provided information and interpretation at the site. The importance of these items for satisfaction have been highlighted in previous literature (e.g. Lee, Petrick \& Crompton, 2007; De Rojas \& Camarero, 2008) and thus, visitors were asked to evaluate the quality of information panels, brochures and guides. The fifth item of the dimension "Interpretation" was included to identify whether the visitor has learned why the heritage sites is considered to be of universal cultural value. The evaluation of this question ought to shed light on the emphasis that is put on explaining for which reasons the site was awarded the UNESCO label. 
The fourth section ("Satisfaction") aimed at assessing the visitors' satisfaction with their visit to the World Heritage Site. Items referred to satisfaction with provided information, service, the management's effort to make the site interesting and enjoyable and a concluding evaluation of overall satisfaction. After "Experience Quality" this section represented the second part of the theoretical model of this study. As the last section of the questionnaire and third part of the model, "Behavioural Intention" of the visitors was surveyed. Instead of the intention to return to the site, the items asked referred to the intention to recommend and visit other UNESCO sites in Oman based on the experience made. These items have been proven to be better indicators for future behaviour in the tourism context (McIntosh 2004; Moscardo \& Pearce 1999; Prentice 1993). At last, visitors should state their willingness to pay a higher entrance fee to enter the site as it has been done in previous studies (e.g. Chen \& Tsai 2007; Oppermann 2000). This item was included to provide basic information for future calculation of prices. 350 questionnaires were prepared and 250 filled in adequately and considered valid ( $\mathrm{N}=250$; response rate of $71.4 \%$ ). $60 \%$ $\left(\mathrm{N}_{\mathrm{a}}=150\right)$ were completed in Oasis of Bahla and $40 \%\left(\mathrm{~N}_{\mathrm{b}}=100\right)$ for Land of Frankincense. In Bahla, the questionnaires were distributed to the visitors during regular opening hours and by the cashier after their visit. Time to fill in the questionnaire ranged between 5 and 10 minutes and respondents were free to choose where to complete it.

\section{Results}

\subsection{Methods of data analysis}

In terms of software, IBM Statistical Package for Social Sciences (SPSS) version 24 was used for analysis. Statistical tools that were used are descriptive analysis, descriptive statistics, differential analysis, correlation analysis and cross tabulation. Demographics and travel pattern were presented through descriptive analysis and sections and dimensions evaluated by employing descriptive statistics. Differential analysis was used to analyse differences between the two UNESCO sites whereas correlation analysis provided results to test hypotheses dealing with significance of relationships between sections and dimensions. In order to test relationships between individual items and gain knowledge on connections between certain types of behaviour, Cross tabulation and Pearson Chi-Square Test were utilized. The basic descriptive analysis was conducted to gain information about the chosen sample and the travel behaviour. Furthermore, differences between the UNESCO sites were identified. Frequencies and percentages together with mean score and standard deviation were examined through descriptive statistics. Mean scores were analysed to make statements regarding the perceived experience quality, satisfaction and behavioural intention. This process was followed for each heritage site individually. Correlation analysis was used to test hypotheses 1 and 2. The Pearson coefficient of relationships between sections and dimensions indicated significance and provided evidence to draw conclusions. Differences between the analysed UNESCO sites in terms of mean scores were identified through differential analysis. The resulting Analysis of Variance (ANOVA)-tables with the associated $p$-values provided the requested information for the testing of $\mathrm{H} 3$ and $\mathrm{H} 4$. Hypotheses 5 and 6 were tested by utilizing cross tabulation and the Pearson Chi-square test which provided information about relationships between scale measures. Sections, dimensions, attributes or items were considered to be equal in importance and therefore not weighted. 


\subsection{Demographic profile of respondents.}

Table 1 summarizes the demographic information gained from the survey. A relatively even gender distribution was found with a share of $47.2 \%$ female and $52.8 \%$ male respondents. The strongest representation in terms of age was found in the group of 25-34 years with $28.8 \%$. The following groups showed a balanced outcome with $15.6 \%$ for $35-44$ years and respectively $16.8 \%$ of the age between 45-54 and 55-64. The two ends of the spectrum are $7.6 \%$ of young adults between 18 and 24 and $14.4 \%$ senior citizens of the age of 65 and older. The sample mainly consisted of visitors with academic background. Combining the positive responses to the options "University" (32.8\%), "Graduate" $(47.2 \%)$ and " $\mathrm{PhD}$ " (8.4\%) leads to a total of $88.4 \%$. $11.6 \%$ of the visitors answered that they have received basic education which includes all possibilities outside university education. To have an approximate idea of the journey that the visitor made, the question of residency was asked. $90.4 \%$ respondent to be an international tourist and accordingly, 9.6\% are residents in the Sultanate of Oman. This does not mean that these visitors are born in Oman but that they are not in a situation of only visiting the country and most probably permanently live and work there. The question of residence also was the only one with noticeable differences between Oasis of Bahla and Land of Frankincense. In Bahla, 17\% stated to be Omani residents $(83 \%$ international tourists) and in Land of Frankincense, only $4.7 \%$ are residents $(95.3 \%$ international tourists). All other demographical questions showed very similar answers and distributions for both UNESCO sites.
Table 1: Results for the analysis of demographics (frequencies and percentages) of the study sample

\begin{tabular}{lll}
\hline Demographics & F. & \% \\
\hline Gender & 118 & 47.2 \\
Female & 132 & 52.8 \\
Male & & \\
Age & 19 & 7.6 \\
18-24 & 72 & 28.8 \\
25-34 & 39 & 15.6 \\
35-44 & 42 & 16.8 \\
$45-54$ & 42 & 16.8 \\
55-64 & 36 & 14.4 \\
65 and over & & \\
Education & 29 & 11.6 \\
Basic & 82 & 32.8 \\
University & 118 & 47.2 \\
Graduate & 21 & 8.4 \\
PhD & & \\
Residency & & 9.6 \\
A resident of & 24 & 90.4 \\
Oman & & \\
An International & 226 & \\
Tourist & & \\
\hline
\end{tabular}

\subsection{Descriptive statistics for the Oasis of Bahla}

The descriptive statistics present the visitor ratings of the dimensions and attributes as well as the overall satisfaction and post-visit behavioural intentions of the tourist for each of the analysed UNESCO sites. The results indicated that in the perception of the respondents, two of the dimensions were satisfactory, one was measured as indifferent and one of them had to be considered unsatisfactory. In terms of the 20 attributes, nine were found to be satisfactory, six as indifferent and five as dissatisfactory (See Table 2).

The mean score for the dimension "Physical appearance and maintenance" consisting of four attributes was 4.0600. Therefore, it is slightly above the "Agree"-level and can be 
considered satisfactory as perceived by the visitors. In terms of the dimension "Accessibility" provided the highest satisfaction for visitors in Oasis of Bahla with a mean score of 4.3967 . The dimension of "Facilities and employees" scored a mean of 3.333 but the mean for the attributes range from 2.7467 to 4.0800 . The dimension "Interpretation" was marginally rated as dissatisfactory by the respondents with a mean of 2.9187". This score is very close to being considered indifferent; however, single attributes show a clearer tendency. The overall experience including all dimensions and attributes resulted in a mean of 3.6772 which shows a clear tendency towards satisfaction.
The drivers of this result are the dimensions of physical appearance and accessibility. In terms of satisfaction (mean: 3.3383), the results show a balanced picture with means ranging from 2.8200 to 3.7600 . Despite of this mix of opinions for satisfaction, over $80 \%$ of respondents made clear that they would recommend other people to visit the site (mean: 4.2067) and 61.3\% would visit other UNESCO sites in Oman based on their visit to Oasis of Bahla. An increased entrance fee would also be accepted by over $45 \%$ of the sample for Bahla and refused by $20.7 \%$ leaving $34 \%$ of visitors who did not have an opinion on this matter.

\subsection{Descriptive statistics for the Land of Frankincense}

In case of the UNESCO site of Land of Frankincense, all four dimensions have been identified as satisfactory for visitors according to categories that have been established for the means (See Table 3). However, two of the dimensions were very close to being considered as indifferent and also six attributes did not achieve a satisfactory level but have been perceived as indifferent by the respondents. Accordingly, the remaining fourteen attributes are above the mean of 3.5. The dimension "Facilities and Employees" achieved a mean (3.5833) close to the middle of the scale. Also the mean score 3.5120 of "Interpretation" did not conclude strong opinions. The dimension with the second highest mean was found to be "Accessibility" (3.9350). A mean of 3.7832 was calculated for the satisfaction with all the attributes combined ("Experience Quality"). This is similar to the result discovered for Oasis of Bahla. However, a considerably higher mean was found for the overall satisfaction of the respondents. 
Table 2 Results of the analysis of variables and dimensions (frequencies and percentages) for the Oasis of Bahla

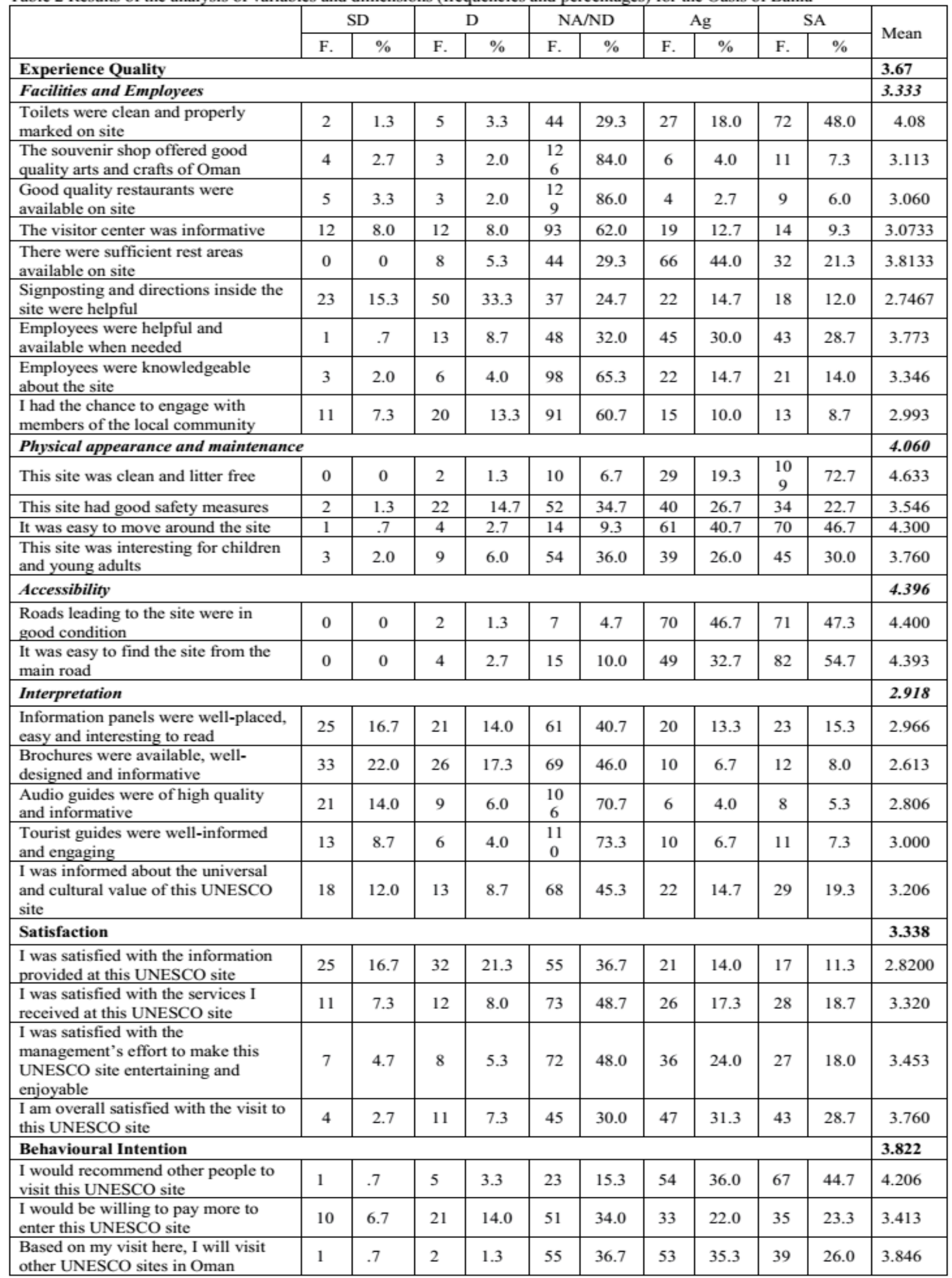


Table 3 Results of the analysis of variables and dimensions (frequencies and percentages) for the Land of Frankincense

\begin{tabular}{|c|c|c|c|c|c|c|c|c|c|c|c|}
\hline & \multicolumn{2}{|c|}{ SD } & \multicolumn{2}{|c|}{ D } & \multicolumn{2}{|c|}{ NA/ND } & \multicolumn{2}{|c|}{$\mathrm{Ag}$} & \multicolumn{2}{|c|}{ SA } & \multirow{2}{*}{ Mean } \\
\hline & F. & $\%$ & F. & $\%$ & F. & $\%$ & F. & $\%$ & F. & $\%$ & \\
\hline \multicolumn{11}{|l|}{ Experience Quality } & 3.7832 \\
\hline \multicolumn{11}{|l|}{ Facilities and Employees } & 3.5833 \\
\hline $\begin{array}{l}\text { Toilets were clean and properly marked on } \\
\text { site }\end{array}$ & 0 & 0 & 10 & 10.0 & 27 & 27.0 & 40 & 40.0 & 23 & 23.0 & 3.7600 \\
\hline $\begin{array}{l}\text { The souvenir shop offered good quality arts } \\
\text { and crafts of Oman }\end{array}$ & 0 & 0 & 1 & 1.0 & 49 & 49.0 & 43 & 43.0 & 7 & 7.0 & 3.5600 \\
\hline $\begin{array}{l}\text { Good quality restaurants were available on } \\
\text { site }\end{array}$ & 0 & 0 & 5 & 5.0 & 77 & 77.0 & 14 & 14.0 & 4 & 4.0 & 3.1700 \\
\hline The visitor center was informative & 2 & 2.0 & 3 & 3.0 & 45 & 45.0 & 36 & 36.0 & 14 & 14.0 & 3.5700 \\
\hline $\begin{array}{l}\text { There were sufficient rest areas available on } \\
\text { site }\end{array}$ & 0 & 0 & 7 & 7.0 & 22 & 22.0 & 41 & 41.0 & 30 & 30.0 & 3.9400 \\
\hline $\begin{array}{l}\text { Signposting and directions inside the site were } \\
\text { helpful }\end{array}$ & 0 & 0 & 13 & 13.0 & 30 & 30.0 & 43 & 43.0 & 14 & 14.0 & 3.5800 \\
\hline $\begin{array}{l}\text { Employees were helpful and available when } \\
\text { needed }\end{array}$ & 0 & 0 & 2 & 2.0 & 41 & 41.0 & 25 & 25.0 & 32 & 32.0 & 3.8700 \\
\hline Employees were knowledgeable about the site & 2 & 2.0 & 2 & 2.0 & 47 & 47.0 & 29 & 29.0 & 20 & 20.0 & 3.6300 \\
\hline $\begin{array}{l}\text { I had the chance to engage with members of } \\
\text { the local community }\end{array}$ & 3 & 3.0 & 12 & 12.0 & 60 & 60.0 & 15 & 15.0 & 10 & 10.0 & 3.1700 \\
\hline \multicolumn{11}{|l|}{ Physical appearance and maintenance } & 4.1025 \\
\hline This site was clean and litter free & 1 & 1.0 & 3 & 3.0 & 9 & 9.0 & 20 & 20.0 & 67 & 67.0 & 4.4900 \\
\hline This site had good safety measures & 0 & 0 & 2 & 2.0 & 27 & 27.0 & 32 & 32.0 & 39 & 39.0 & 4.0800 \\
\hline It was easy to move around the site & 0 & 0 & 0 & 0 & 13 & 13.0 & 26 & 26.0 & 61 & 61.0 & 4.4800 \\
\hline $\begin{array}{l}\text { This site was interesting for children and } \\
\text { young adults }\end{array}$ & 2 & 2.0 & 16 & 16.0 & 39 & 39.0 & 30 & 30.0 & 13 & 13.0 & 3.3600 \\
\hline \multicolumn{11}{|l|}{ Accessibility } & 3.9350 \\
\hline $\begin{array}{l}\text { Roads leading to the site were in good } \\
\text { condition }\end{array}$ & 1 & 1.0 & 2 & 2.0 & 33 & 33.0 & 26 & 26.0 & 38 & 38.0 & 3.9800 \\
\hline It was easy to find the site from the main road & 1 & 1.0 & 3 & 3.0 & 40 & 40.0 & 18 & 18.0 & 38 & 38.0 & 3.8900 \\
\hline \multicolumn{11}{|l|}{ Interpretation } & 3.5120 \\
\hline $\begin{array}{l}\text { Information panels were well-placed, easy and } \\
\text { interesting to read }\end{array}$ & 2 & 2.0 & 6 & 6.0 & 28 & 28.0 & 37 & 37.0 & 27 & 27.0 & 3.8100 \\
\hline $\begin{array}{l}\text { Brochures were available, well-designed and } \\
\text { informative }\end{array}$ & 2 & 2.0 & 7 & 7.0 & 52 & 52.0 & 24 & 24.0 & 15 & 15.0 & 3.4300 \\
\hline $\begin{array}{l}\text { Audio guides were of high quality and } \\
\text { informative }\end{array}$ & 4 & 4.0 & 0 & 0 & 70 & 70.0 & 19 & 19.0 & 7 & 7.0 & 3.2500 \\
\hline $\begin{array}{l}\text { Tourist guides were well-informed and } \\
\text { engaging }\end{array}$ & 2 & 2.0 & 5 & 5.0 & 45 & 45.0 & 29 & 29.0 & 19 & 19.0 & 3.5800 \\
\hline $\begin{array}{l}\text { I was informed about the universal and } \\
\text { cultural value of this UNESCO site }\end{array}$ & 5 & 5.0 & 12 & 12.0 & 32 & 32.0 & 31 & 31.0 & 20 & 20.0 & 3.4900 \\
\hline \multicolumn{11}{|l|}{ Satisfaction } & 3.9675 \\
\hline $\begin{array}{l}\text { I was satisfied with the information provided } \\
\text { at this UNESCO site }\end{array}$ & 2 & 2.0 & 10 & 10.0 & 18 & 18.0 & 42 & 42.0 & 28 & 28.0 & 3.8400 \\
\hline $\begin{array}{l}\text { I was satisfied with the services I received at } \\
\text { this UNESCO site }\end{array}$ & 2 & 2.0 & 2 & 2.0 & 31 & 31.0 & 37 & 37.0 & 28 & 28.0 & 3.8700 \\
\hline $\begin{array}{l}\text { I was satisfied with the management's effort } \\
\text { to make this UNESCO site entertaining and } \\
\text { enjoyable }\end{array}$ & 1 & 1.0 & 1 & 1.0 & 24 & 24.0 & 42 & 42.0 & 32 & 32.0 & 4.0300 \\
\hline $\begin{array}{l}\text { I am overall satisfied with the visit to this } \\
\text { UNESCO site }\end{array}$ & 0 & 0 & 3 & 3.0 & 18 & 18.0 & 42 & 42.0 & 37 & 37.0 & 4.1300 \\
\hline \multicolumn{11}{|l|}{ Behavioural Intention } & 3.7733 \\
\hline $\begin{array}{l}\text { I would recommend other people to visit this } \\
\text { UNESCO site }\end{array}$ & 2 & 2.0 & 2 & 2.0 & 11 & 11.0 & 42 & 42.0 & 43 & 43.0 & 4.2200 \\
\hline $\begin{array}{l}\text { I would be willing to pay more to enter this } \\
\text { UNESCO site }\end{array}$ & 8 & 8.0 & 20 & 20.0 & 36 & 36.0 & 20 & 20.0 & 16 & 16.0 & 3.1600 \\
\hline $\begin{array}{l}\text { Based on my visit here, I will visit other } \\
\text { UNESCO sites in Oman }\end{array}$ & 0 & 0 & 6 & 6.0 & 22 & 22.0 & 44 & 44.0 & 28 & 28.0 & 3.9400 \\
\hline
\end{tabular}


The result of 3.9675 let the author conclude that most of the visitors left the site with a feeling for satisfaction. This is also indicated by the individual means for the four different attributes. $70 \%$ were satisfied with the information provided on-site and $12 \%$ did not receive as much information as they would have liked. $37 \%$ agreed to be satisfied with the received services and $28 \%$ even strongly agreed. $4 \%$ could not agree and $31 \%$ neither agreed nor disagreed. 74 out of 100 visitors agreed (42) and strongly agreed (32) to be satisfied with the management's effort to make the site interesting and enjoyable. The positive behavioural intentions of the visitors were slightly weaker than in Oasis of Bahla with a mean of 3.7733 . Nonetheless, $83 \%$ of respondents would recommend the UNESCO site to other people and $4 \%$ would refrain from doing so. $6 \%$ will not visit other UNESCO sites in Oman based on their visit to Land of Frankincense though $72 \%$ agree or strongly agree to visit one or more of the remaining WHSs in Oman. 28\% stated that they cannot support an increase of entrance fees and $36 \%$ did not have an opinion on the matter. The residuary percentage (36\%) would be willing to pay more to enter the UNESCO site.

\subsection{Testing of hypotheses}

Purposively for this study, six major hypotheses are being proposed and tested whereas $\mathrm{H} 1$ includes four, $\mathrm{H} 3$ two and $\mathrm{H} 4$ three sub-hypotheses. For the first part and through correlation analysis (Pearson Correlation), the relationship between experience and satisfaction ( $\mathrm{H} 1)$, the four dimensions and satisfaction (H1a; H1b; H1c; H1d) as well as the relationship between satisfaction and behavioural intention (H2) are tested for significance. Secondly, differential analysis with Analysis of Variance (ANOVA) is employed to find evidence for the support or rejection of hypotheses $\mathrm{H} 3, \mathrm{H} 3 \mathrm{a}$ and $\mathrm{H} 3 \mathrm{~b}$ which involve significant differences between the two UNESCO sites in terms of experience (H3), satisfaction (H3a) and behavioural intention (H3b) and general assumptions regarding the relationship between travel pattern and satisfaction $(\mathrm{H} 4 ; \mathrm{H} 4 \mathrm{a} ; \mathrm{H} 4 \mathrm{~b} ; \mathrm{H} 4 \mathrm{c})$. At last, relationships within the travel pattern are being assessed by utilizing Cross tabulation and the Pearson Chi-Square Test to indicate if the results are significant. Hypothesis 5 alleges that a connection between the time spent on-site and the amount of money that was spent (H5) exists while hypothesis 6 relates the nature of the visitor's trip to the spending (H6) to explore if for example cruise passengers are willing to spend more than visitors on self-organized holidays.

\section{Hypothesis 1}

$\mathrm{H} 1$ : There is a positive and significant relationship between "Experience Quality" and "Satisfaction"

For the WHS of Oasis of Bahla $\left(\varrho=.735^{* *}\right)$ as well as for Land of Frankincense $\left(\rho=.561^{* *}\right)$ and the overall analysis of both sites combined $(\varrho=.667 * *)$ a positive and significant relationship has been found (See Table 4). This means that if the perceived quality of the experience is high, the satisfaction will be high and an increase in perceived experience quality triggers an increase in satisfaction. The coefficient is higher for Oasis of Bahla which indicates that visitors to the site connected their experience even more strongly to their overall satisfaction. Hypothesis 1 is confirmed and can be accepted. 


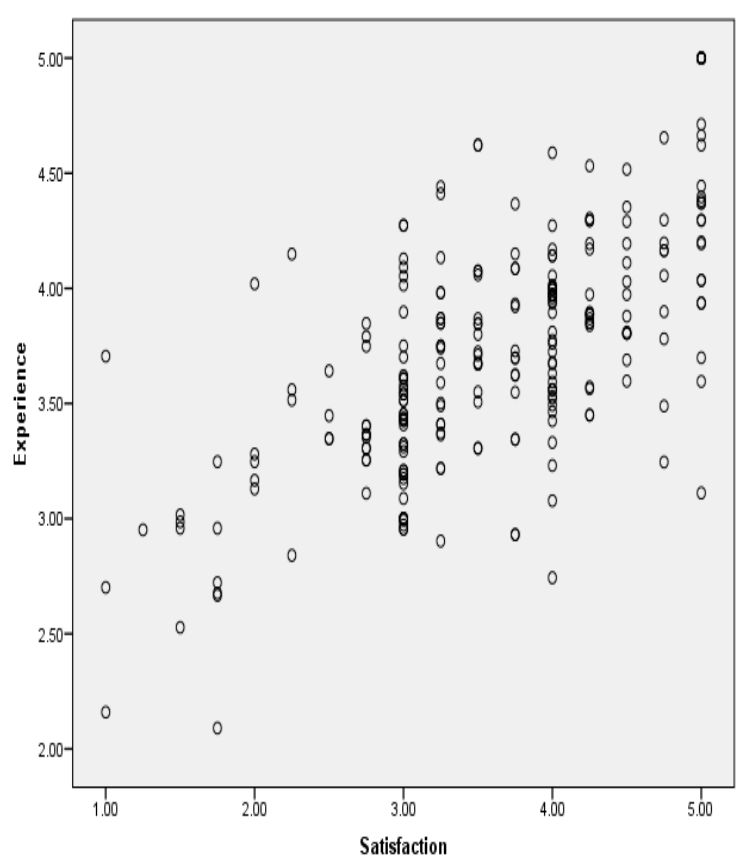

Figure 2: Scatter-diagram of the relationship between Experience and Satisfaction for the entire sample.

\section{Hypothesis 1a}

H1a: There is a positive and significant relationship between the dimension "Facilities and employees" and overall "Satisfaction"

Hypothesis 1a is supported by the findings and can be accepted since a positive and significant relationship exists between "Facilities and employees" and "Satisfaction". Again, the strongest relationship was found for Oasis of Bahla with a PCC of $\varrho=.711 * *$. For Land of Frankincense, the coefficient amounts to $\varrho=.521 * *$ and overall to $\varrho=.672 * *$. The coefficients indicate that the satisfaction with the facilities on-site plays an important role for the overall satisfaction and that changes made for the attributes in this dimension have an effect on the customer's overall evaluation of the visit.

\section{Hypothesis 1b}

$\mathrm{H} 1 \mathrm{~b}$ : There is a positive and significant relationship between the dimension "Physical appearance and maintenance" and overall "Satisfaction"

The physical appearance of the Oasis of Bahla World Heritage Site reveals a strong relationship between its perception by the visitor and his or her satisfaction $(\varrho=.493 * *)$. For Land of Frankincense a similar finding was made with a PCC of $\varrho=.310^{* *}$ ). Overall the correlation analysis results in a significance coefficient of $\varrho=.411^{*} *$. Generally, the coefficient is lower than for the first dimensions ("Facilities and employees") but nonetheless the relationship is highly significant in all cases and therefore $\mathrm{H} 1 \mathrm{~b}$ is supported by the findings.

\section{Hypothesis 1c}

H1c: There is a positive and significant relationship between the dimension "Accessibility" and overall "Satisfaction"

Although still a positive and significant correlation, the relationship between "Accessibility" and "Satisfaction" shows the lowest coefficients for Oasis of Bahla $\left(\varrho=.378^{* *}\right)$, Land of Frankincense $\left(\varrho=.321^{* *}\right)$ and for both sides in total $\left(\varrho=.210^{* *}\right)$. Although the means of transportation can be considered different for the two UNESCO sites (Oasis of Bahla often reached by car whereas in Frankincense buses are used in the majority of cases), the results show that it is not the most important factor for the visitor and that other dimensions have a stronger relationship with the overall satisfaction. However, significance is recognized and also Hypothesis 1c is accepted due to its support from the findings.

\section{Hypothesis 1d}

H1d: There is a positive and significant relationship between the dimension "Interpretation" and overall "Satisfaction" 
For hypothesis 1d, findings likewise provide support for the acceptance. For the overall analysis and individually for Land of Frankincense, the Pearson Correlation Coefficients let conclude that "Interpretation" has the strongest relationship with "Satisfaction" when comparing the relationships between the other dimensions and "Satisfaction". Overall $\varrho=.692 * *$ and for
Land of Frankincense $\varrho=.523 * *$ which indicates that interpretation and learning onsite is essential for the visitor and strongly influences the satisfaction. For Oasis of Bahla the relationship is highly significant $(\varrho=.707 * *)$ but not as strong as between the perceived quality of facilities and overall satisfaction.

\section{Hypothesis 2}

$\mathrm{H} 2:$ There is a positive and significant relationship between "Satisfaction" and "Behavioural Intention"

It was proven that the perceived quality of the entire experience influences the overall satisfaction of the visitor. As a second step, it is analysed whether the relationship continues, and "Satisfaction" also has a positive and significant relationship with the "Behavioural Intention" of the visitor post-visit. The Pearson Correlation clearly gives evidence that this relationship exists in a strong form for each case.

Table 4 Results of the analysis of significance between dimensions and satisfaction and satisfaction and behavioural intention

\section{Satisfaction}

Oasis of Frankin.

Bahla Land
Behavioural Intention

Oasis of Frankin.

Bahla Land Combined

\begin{tabular}{llllllll}
\hline 3. & $\begin{array}{l}\text { Experience } \\
\text { Quality }\end{array}$ & $.735^{* *}$ & $.561^{* *}$ & $.667^{* *}$ & $.465^{* *}$ & $.509^{* *}$ & $.475^{* *}$ \\
3.1 & $\begin{array}{l}\text { Facilities and } \\
\text { employees }\end{array}$ & $.711^{* *}$ & $.521^{* *}$ & $.672^{* *}$ & $.422^{* *}$ & $.503^{* *}$ & $.432^{* *}$ \\
3.2 & $\begin{array}{l}\text { Physical } \\
\text { appearance }\end{array}$ & $.493^{* *}$ & $.310^{* *}$ & $.411^{* *}$ & $.353^{* *}$ & $.335^{* *}$ & $.344^{* *}$ \\
3.3 & $\begin{array}{l}\text { Accessibility } \\
3.4\end{array}$ & $.378^{* *}$ & $.321^{* *}$ & $.210^{* *}$ & $.369^{* *}$ & $.336^{* *}$ & $.343^{* *}$ \\
4 & $\begin{array}{l}\text { Interpretation } \\
\text { Satisfaction }\end{array}$ & $.707^{* *}$ & $.523^{* *}$ & $.692^{* *}$ & $.341^{* *}$ & $.351^{* *}$ & $.311^{* *}$ \\
5 & $\begin{array}{l}\text { Behavioural } \\
\text { Intention }\end{array}$ & $.563^{* *}$ & $.754^{* *}$ & $.579^{* *}$ & 1 & 1 & 1 \\
\hline$* *$ & Correlation is significant at the 0.01 level (2-tailed). & & & $.59^{* *}$ \\
$*$. & Correlation is significant at the 0.05 level (2-tailed). & & &
\end{tabular}


For Oasis of Bahla the PCC is $\varrho=.563^{* *}$ and for Land of Frankincense $\varrho=.754 * *$ which is the strongest relationship overall that has been found out of the relationships analysed for this site. Assessing the relationship for both WHS together results in $\varrho=.579 * *$ which is also highly significant. With the findings discussed, $\mathrm{H} 2$ is supported and therefore accepted as confirmed.

\subsection{Differential analysis}

For two reasons, a differential analysis has been conducted. First of all, it was important to gain knowledge on the significant differences between the dimensions and attributes of the two UNESCO sites (hypotheses 3-5). In order to identify significance, the means for Oasis of Bahla and Land of Frankincense have been compared with the attributes in the dependent list. The resulting ANOVA-table showed the comparison of attributes and dimensions of the experience as well as differences in overall satisfaction and behavioural intention. What has to be kept in mind is the already mentioned influence of the middle answer "Neither agree nor disagree" which was the intended option for the respondents when the specific attribute was not available on-site.

Secondly, connections between travel behaviour and satisfaction were to be assessed (hypothesis 6-6c) for the purpose of identifying patterns that help to understand if certain factors also have influence on satisfaction. Here, the entire sample has been used to assess the overall significance, but all tests have been conducted again for each individual site. Only when significant differences between the sites were identified, they were mentioned below. In the following, hypotheses 3 to $6 \mathrm{c}$ are being tested with respect to the relationship between means and the calculated significance. Confirmation or dismissal of the hypotheses is based on these findings. However, Table 5 also provides information for each site individually and important differences are mentioned. It was decided to declare differences as significant when a $p$-value of $\leq 0.05$ has been identified resulting in a percentage of confidence of $95 \%$ which leaves a 5\% mistake chance. In general, only dimensions and attributes that fit this categorization are being mentioned.

\section{Hypothesis 3}

H3: There is a significant difference in "Experience Quality" between the analysed UNESCO sites

ANOVA results states a probability value of .112 for the overall experience that visitors had at the sites. This shows that there is no significant difference in the overall experience of the visitor when including all four dimensions ("Facilities and employees", "Physical appearance and maintenance", "Accessibility" and "Interpretation"). However, significance can be found in three of the four dimensions and 13 of the 20 attributes.

"Facilities and employees" with a $p$-value of .001 clearly demonstrates significant differences. In terms of attributes, the ratings for washrooms (.012), the souvenir shop (.000) and the visitor centre (.000) likewise are significantly different between the sites. A logical explanation for the differences of the latter named attributes is the lack of them at Oasis of Bahla. A souvenir shop is not existent and neither a visitor centre is available on-site. A $100 \%$ significance was also computed in regard to signposting and directions indicating entrance, exit and general points of interest. Here, Land of Frankincense reaches considerably higher means for two reasons. Again, direction or supportive signposting is not available at the WHS of Oasis of Bahla except for a sign leading to the washrooms. 
Some of the rooms of the fort have names on them but due to the size of the fort, those plates cannot be seen from most places. Land of Frankincense, although also comprised of a large area does not face the same problem since the path along the site is easily recognizable and the museum can be seen from anywhere on-site. However, the survey results also indicated that visitors are not completely satisfied with the arrangement and therefore improvements are needed at both WHSs. Another significant difference (.012) was identified for the perceived knowledge of employees. Visitors were more satisfied with the knowledge provided at Land of Frankincense, however, it is not clear whether visitors also based this evaluation on their tour guides which have been employed considerably more frequently in Land of Frankincense, although they are not part of the WHS. Furthermore, Bahla has fewer employees and usually the cashier providing the tickets is the only human source of information. This is why it has to be considered that many visitors did have less contact with employees in Bahla which degrades the mean although it is still clearly pending in the positive range.

Although the dimension "Physical appearance and maintenance" does not show significance, two of the attributes have been perceived differently by respondents. Even though visitors acknowledged a sufficient level of safety at both sites, a $p$-value of .000 was identified. Reasons for this significance of $100 \%$ can lie in the nature of the two sites. While Land of Frankincense is easy to explore, Oasis of Bahla consists of many individual rooms connected by stairs which let the visitor walk on different levels of the fort. Certainly, this holds more risks to fall and cause an injury but at the same time, a large array of security barriers would change the appearance of the WHS and include materials that were not common at the point of emergence. Furthermore, connected to the nature of the UNESCO sites might be the significant difference in the perception of suitability for children. At Oasis of Bahla, children seem to be more entertained than in Land of Frankincense what can be connected to the mentioned lack of barriers which allows the visitor to explore almost the entire fort.

"Accessibility" reveals 100\% significance for both included attributes and therefore for the whole dimension (.000). Road condition and easiness in finding the particular site from the main road have been perceived positive for Land of Frankincense but extraordinarily high means were achieved for Oasis of Bahla. Although both sites are located close to main roads, Bahla provokes attention through its size and can be seen from kilometres away. Another assumption to explain the difference is the usage of transport to reach the sites. While most of the visitors use cars to visit Oasis of Bahla, it was recognized that often large groups arrive to Land of Frankincense with coaches or smaller groups and families with taxis and therefore probably have no perception and are indifferent of these attributes. The assumption is also supported by the significant higher amount of cruise ship passengers in Land of Frankincense who are driven to the site and therefore do not have to find the WHS on their own.

For five out of six attributes of the "Interpretation" dimension a significance level of $100 \%$ has been computed which also applies for the overall result. Information panels are nearly not to be found in Oasis of Bahla whereas Land of Frankincense provides information especially in the museums on-site. This led to a significant difference in satisfaction for the visitor. The same applies for tourists guides since most visitors visited 
Oasis of Bahla without a guide and therefore were indifferent about the quality. Usually, larger groups of visitors were taken through the premises of Land of Frankincense which justifies an opinion regarding satisfaction with the service. A higher satisfaction level was reached in terms of provided brochures in Land of Frankincense with a $p$-level of .000 in comparison to Oasis of Bahla where brochures are not provided.

Although significant differences have been found for a variety of attributes and three out of four dimensions, the overall experience at the two WHS has not been perceived significantly different. This means that hypothesis 3 is not supported by the findings of the survey and has to be rejected.

\section{Hypothesis 3a}

H3a: There is a significant difference in "Satisfaction" between the analysed UNESCO sites

Difference in satisfaction was expected to be found in the comparison between Oasis of Bahla and Land of Frankincense. This hypothesis is support by the $p$-level (.000) computed. The information received in Oasis of Bahla have not been perceived as satisfying for most of the visitors. Interpretation was not sufficient, and visitors did not feel like they learned enough from the visit. A higher level of satisfaction was achieved for Land of Frankincense. Service is perceived significantly different between the sites although in neither of the cases visitors were generally dissatisfied. The same applies to the statement that the management's effort to make the site entertaining and enjoyable was satisfying. The conclusive statement regarding the overall satisfaction shows a $p$-level of .003 and therefore also has been perceived significantly different in comparison. Visitors in Land of Frankincense showed a higher satisfaction level in overall terms which was to be expected considering the significance of the previous items. In both cases, visitors were thoroughly satisfied but the availability of certain facilities and interpretation on-site was decisive for the general view.

\section{Hypothesis 3b}

$\mathrm{H} 3 \mathrm{~b}$ : There is a significant difference in "Behavioural Intention" between the analysed UNESCO sites

The differential analysis showed no significance between stated behavioural intentions at Oasis of Bahla and Land of Frankincense. Although various attributes have been rated significantly different, in each case the results give evidence (with an over $90 \%$ conformity) that visitors value the WHSs enough in order to confidently recommend it to other people. An increase of entrance fees was not dismissed for either of the sites and for a large part of the respondents a visit to another UNESCO site in Oman is possible based on the experience in Bahla or Land of Frankincense. Accordingly, hypothesis $3 b$ has not been supported by the research and has to be rejected.

\section{Hypothesis 4}

H4: Visitors who spent more money on-site were significantly more satisfied with their visit

As can be identified from the significance coefficient in Table 6 , in the cases of Oasis of Bahla ( $p$-value: .001) and the overall sample ( $p$-value: .000), significant differences in satisfaction can be found among visitors who spent "less than 1 OMR", "1 to 5 OMR", "6 to 10 OMR", "10 to 15 OMR" and "more than 15 OMR". Apart from "more than 15 OMR", the mean of satisfaction rises in each category indicating a higher satisfaction with the visit 
when more money was spent on-site up to a certain point. Although it was not the case for Land of Frankincense, the findings show that visitors do not feel less satisfied when they spend more money. In contrast, their satisfaction increases from purchasing food and beverages for relaxation and regaining energy. Also wondering around the souvenir shop including buying something to remember the visit seems to satisfy the respondent. Considering these findings and the emphasis of the whole sample, hypothesis 4 can be accepted.

\begin{tabular}{|c|c|c|}
\hline $\begin{array}{l}\text { Oasis of Bahla } \\
\text { Mean }\end{array}$ & $\begin{array}{l}\text { Land of } \\
\text { Frankincense } \\
\text { Mean }\end{array}$ & Sig. $p$-Value \\
\hline $\begin{array}{l}\text { Experience Quality } \\
3.6772\end{array}$ & 3.7832 & .112 \\
\hline \multicolumn{3}{|c|}{ Facilities and employees } \\
\hline 3.3333 & 3.5833 & .001 \\
\hline 4.0800 & 3.7600 & .012 \\
\hline 3.1133 & 3.5600 & .000 \\
\hline 3.0600 & 3.1700 & .169 \\
\hline 3.0733 & 3.5700 & .000 \\
\hline 3.8133 & 3.9400 & .254 \\
\hline 2.7467 & 3.5800 & .000 \\
\hline 3.7733 & 3.8700 & .431 \\
\hline 3.3467 & 3.6300 & .012 \\
\hline 2.9933 & 3.1700 & .136 \\
\hline \multicolumn{3}{|c|}{ Physical appearance and maintenance } \\
\hline 4.0600 & 4.1025 & .583 \\
\hline 4.6333 & 4.4900 & .141 \\
\hline 3.5467 & 4.0800 & .000 \\
\hline 4.3000 & 4.4800 & .071 \\
\hline 3.7600 & 3.3600 & .002 \\
\hline \multicolumn{3}{|l|}{ Accessibility } \\
\hline 4.3967 & 3.9359 & .000 \\
\hline 4.4000 & 3.9800 & .000 \\
\hline 4.3933 & 3.8900 & .000 \\
\hline \multicolumn{3}{|l|}{ Interpretation } \\
\hline 2.9187 & 3.5120 & .000 \\
\hline 2.9667 & 3.8100 & .000 \\
\hline 2.6133 & 3.4300 & .000 \\
\hline 2.8067 & 3.2500 & .000 \\
\hline 3.0000 & 3.5800 & .000 \\
\hline 3.2067 & 3.4900 & .060 \\
\hline \multicolumn{3}{|l|}{ Satisfaction } \\
\hline 3.3383 & 3.9675 & .000 \\
\hline 2.8200 & 3.8400 & .000 \\
\hline 3.3200 & 3.8700 & .000 \\
\hline 3.4533 & 4.0300 & .000 \\
\hline \multirow{2}{*}{\multicolumn{3}{|c|}{ Behavioral Intention }} \\
\hline & & \\
\hline 3.8222 & 3.7733 & .638 \\
\hline 4.2067 & 4.2200 & .906 \\
\hline 3.4133 & 3.1600 & .096 \\
\hline 3.8467 & 3.9400 & .398 \\
\hline
\end{tabular}

Table 5: Results of the analysis of significant differences between Oasis of Bahla and Land of Frankincense

\section{Hypothesis 4a}

H4a: Visitors who spent more time on-site were significantly more satisfied with their visit

The duration of the overall visit does not seem to be an influencing factor towards satisfaction. In none of the cases a significance coefficient equal or lower .05 was identified. Although means of satisfaction are also increasing in each duration category of the entire sample ("less than 1 hour", 1-2 hours", "more than 2 hours"), the rise cannot be considered significant, and hence hypothesis 4a is disconfirmed.

\section{Hypothesis 4b}

$\mathrm{H} 4 \mathrm{~b}$ : Visitors whose main reason to visit the site was the UNESCO label were significantly less satisfied with their visit. Hypothesis $4 \mathrm{~b}$ has to be rejected due to non-significance. The assumption was made to assess whether visitors expect highly developed sites when visiting because of the UNESCO label. This is not supported by the results and therefore satisfaction level is not dependent on the UNESCO label as main driver to visit the heritage site.

\section{Hypothesis 4c}

$\mathrm{H} 4 \mathrm{c}$ : Visitors who have visited other UNESCO sites before were significantly less satisfied with their visit

The $p$-value of .353 reveal that experienced UNESCO World Heritage Site visitors do not have a significantly different satisfaction level than visitors who set foot on a designated site for the first time in the Sultanate of Oman. Therefore, having seen other UNESCO sites before and being able to compare does not 
influence one's satisfaction when visiting another WHS. Accordingly, hypothesis 4c has

to be rejected.

Table 6 Results of the analysis of significant differences in satisfaction between items Spending, Duration and Reason

\begin{tabular}{|c|c|c|c|}
\hline & \multicolumn{3}{|c|}{$\begin{array}{l}\text { Satisfaction } \\
\text { Sig. }\end{array}$} \\
\hline & $\begin{array}{l}\text { Oasis of } \\
\text { Bahla }\end{array}$ & Land of Frankincense & Complete sample \\
\hline Money spent on-site & .001 & .091 & .000 \\
\hline Time spent on-site & .278 & .063 & .229 \\
\hline UNESCO label as reason to visit & .189 & .789 & .302 \\
\hline Visited other UNESCO sites before & .151 & .174 & .353 \\
\hline
\end{tabular}

\section{Hypothesis 5}

H5: There is a significant relationship between the time and money spent on-site

According to the Chi-square presented in Table 7, the duration of the visit is not connected to the amount of money that is being spent. Visitors who inspect the site for a longer time do not tend to spend more money and therefore a significant relationship is not found and hypothesis 5 rejected.

\section{Hypothesis 6}

H6: There is a significant relationship between the nature of the visitor's trip and the money spent

Different types of travellers have spent different amounts of money according to an asymptotic significance of .000 seen in Table
Especially cruise passengers and visitors who visited the sites as part of a travel package spent more money than self-organizers and business travellers.

This might be due to a larger budget for these visitor types who are usually older than visitors who organize trips on their own or travel because of business. The Chi-square (not listed in Table 7 since not part of the hypotheses) confirms this assumption with a $100 \%$ significance between age-group and nature of the trip. Correspondingly, the assumed relationship between trip nature and spending exists and is significant which leads to the acceptance of hypothesis 6 . 13.

Table 7 Results of the analysis of significant differences in satisfaction between items Spending, Duration and Nature.

\begin{tabular}{|c|c|c|c|c|c|c|}
\hline & & \multicolumn{5}{|c|}{ Money spent on-site } \\
\hline & & $\begin{array}{l}\text { Less than } 1 \\
\text { OMR }\end{array}$ & 1-5 OMR & 6-10 OMR & 11-15 OMR & $\begin{array}{l}\text { More than } \\
15 \text { OMR }\end{array}$ \\
\hline \multirow{4}{*}{$\begin{array}{l}\text { Time spent } \\
\text { on-site }\end{array}$} & \multirow{4}{*}{$\begin{array}{l}\text { Less than } 1 \\
\text { hour } \\
1-2 \text { hours } \\
\text { More than } 2 \\
\text { hours } \\
\text { Chi-square: } 115\end{array}$} & $53.2 \%$ & $40.0 \%$ & $16.7 \%$ & $33.3 \%$ & $28.6 \%$ \\
\hline & & $42.1 \%$ & $51.6 \%$ & $66.7 \%$ & $66.7 \%$ & $57.1 \%$ \\
\hline & & $4.8 \%$ & $8.4 \%$ & $16.7 \%$ & $0.0 \%$ & $14.3 \%$ \\
\hline & & & & & & \\
\hline \multirow{5}{*}{$\begin{array}{l}\text { Nature o } \\
\text { f the trip }\end{array}$} & \multirow{4}{*}{$\begin{array}{l}\text { Cruise } \\
\text { Package tour } \\
\text { Self-organized } \\
\text { Business travel }\end{array}$} & $14.3 \%$ & $4.2 \%$ & $0.0 \%$ & $0.0 \%$ & $50.0 \%$ \\
\hline & & $23.0 \%$ & $12.6 \%$ & $25.0 \%$ & $66.7 \%$ & $14.3 \%$ \\
\hline & & $54.8 \%$ & $76.8 \%$ & $41.7 \%$ & $33.3 \%$ & $14.3 \%$ \\
\hline & & $3.2 \%$ & $4.2 \%$ & $16.7 \%$ & $0.0 \%$ & $0.0 \%$ \\
\hline & $\begin{array}{l}\text { Other } \\
\text { Chi-square: .ooo }\end{array}$ & $4.8 \%$ & $2.1 \%$ & $16.7 \%$ & $0.0 \%$ & $21.4 \%$ \\
\hline
\end{tabular}




\section{Discussion of Key Findings}

Experience quality and satisfaction. Timothy and Boyd stated in 2003 that the actual heritage experience is the centre of the discussion of satisfaction. In the case of this study, visitors perceived the quality of the overall experience to be valuable what had a positive and highly significant relationship with the overall satisfaction proven by the use of correlation analysis. Therefore the first part of the model that refers to this relationship has been confirmed what is align with the findings of De Rojas and Camarero (2008) who pointed out that visitor satisfaction often is determined by the entire experience obtained.

Dimensions and satisfaction. All hypotheses stating that positive and significant relationships between the individual dimensions of the experience with their associated attributes and satisfaction exist have been supported by the findings of this study. Moreover, the relationships were all identified to be at .01-level and therefore are highly significant. This process is in accordance with the publication of Pizam et al. (1978) who were among the first researchers to introduce the idea to measure satisfaction based on different dimensions of destination performance which was supported by Churchill and Surprenant (1982) who stated that quality can be measured with attribute performance. In the case of the dimension "Facilities and employees", findings provided evidence that certain facilities are important to increase customer satisfaction. Ramires et al. (2016) names mobility, cleanliness and safety as other attributes of this category. These have been included in the dimension "Physical appearance and maintenance" and referred to by multiple visitors and reviewers. Especially the cleanliness of both UNESCO sites has been highly appreciated. What has to be improved in both cases is the entertainment factor for children. Visitors with kids were unsatisfied with the age restriction of the museum in Land of Frankincense since they were not able to enter without leaving one parent with the child. For Oasis of Bahla it was remarked that children enjoyed the stay, but safety measures have to be improved. "Accessibility" had the weakest relationship with satisfaction but was still highly significant. Also, Jusoh et al. (2013) identified infrastructure to play an important role to make the site attractive for visitors. Roads leading to Oasis of Bahla were perceived as well-developed while visitors in Land of Frankincense were mostly indifferent about the quality.

"Interpretation" was specifically interesting since the strongest relationship with satisfaction was identified for the overall sample and for Land of Frankincense. This is in agreement with the findings from several authors (Poria et al., 2004; Poria et al. 2006; Yankholmes \& Akyeampong, 2010; Goh 2010; Chen \& Chen, 2010) who concluded that the main motivation of visitors visiting heritage sites is education and the strong willingness to learn is one of the most significant indicators of heritage tourists. In this study, the importance of interpretation was identified in each part of the executed analysis. Especially for Oasis of Bahla, where almost no interpretation is provided, visitors were dissatisfied with the situation which resulted in a mean of 2.8200 and multiple mention in the suggestion part of the questionnaire and in reviews on TripAdvisor. Especially brochures were referred to as the fastest, easiest and cheapest way to provide visitors with information. The findings confirm the discoveries of other authors and make clear that visitors that come to heritage sites are highly interested in learning about the history of the place through information panels, 
brochures, guides and all other tools of education. De Rojas and Camarero (2008) also list interpretation as an important determinant of overall satisfaction and argue that it increases the strength of the relationship between site and visitor and results longer duration of the visit with an increase in monetary spending on-site. As the last part of interpretation, the communication of the value of the WHS has been assessed. The universal cultural value as the main reason for a site to be designated as UNESCO World Heritage Site was not made explicit to all visitors. $34 \%$ of them stated to be fully informed at Oasis of Bahla while $51 \%$ confirm the same for Land of Frankincense. Poria et al. (2013, p. 273) found out that visitors link the UNESCO label to "culturally famous" sites with a major significance to humankind. The quality of information provided about the universal cultural value needs to be in accordance with this image in order to give a meaning to the label besides the requirements for protection and conservation.

Satisfaction and behavioural intention. The second part of the model that suggests a positive and significant relationship between visitor satisfaction and behavioural intention post-visit has been confirmed through correlation analysis in all cases measured (Oasis of Bahla, Land of Frankincense and both sites combined). For Land of Frankincense it was the strongest relationship of the entire study. This relationship also has been confirmed by several other studies (e.g. Olsen, 2002; Chen \& Tsai, 2007; Chen \& Chen, 2010; Palau-Saumell et al., 2013) stating that satisfaction is a useful predictor of tourist behaviour after the visit. Hereby, the intention to revisit the site is not the best indicator for heritage sites as discussed by Trinh and Ryan (2013). Therefore, the intention to recommend the place to others, visit similar sites in the future and agreeing on an increase of entrance fee (Chen \& Tsai, 2007; Oppermann, 2000) were more favorable to assess in this study.

\section{Recommendations and Managerial Implications}

From the findings of the study, recommendations can be made for three different levels of authority. Starting with UNESCO, the primarily responsible organisation for WHSs, comments on the questionnaire as well as reviews on TripAdvisor have shown how much visitors appreciated for example the restoration efforts at the Oasis of Bahla, but at the same time heavily criticized the lack of information that has been provided. Although UNESCO is not in charge of developing the site for tourism, the organization does state in its convention that appreciation of the place should be strengthened by implementing educational and information programs to inform the public and communicate the OUV of the site. The outcomes of this and other studies indicate that this objective has not been achieved which consequently means that it would be recommendable for UNESCO to get more involved in the tourism at WHSs.

Also, on the national level improvements can be made. In the case of Oman, it became evident that the structure of ministries is very complex which can lead to confusion and inefficiency. The collaboration between the different authorities involved in protecting and developing WHSs needs revision and the handover of responsibilities must be clearly regulated and made transparent. Here, it could be efficient to establish an Omani UNESCO commission which is in charge of only the UNESCO sites and therefore would unburden the other ministries and develop the WHS 
more efficiently. Furthermore, the government must live up to the statements that have been made in the tourism strategy for 2040 which states that the WHS are main tangible assets which means that a lot more must be done to promote these sites. The designation of the UNESCO label should have a purpose. If it is solely emotional, the current status is sufficient since the places are under protection. However, if the purpose is to use the sites for tourism, efforts should be made to communicate its existence to the potential visitors through online representations which include all necessary information, develop onsite facilities and provide interpretation. At the same time, the balance between tourism infrastructure with an increase in revenue and authenticity has to remain through smart growth and a focus on sustainability. This is especially important since Oman needs to protect its Unique Selling Point (USP) which is the authentic Arabian experience with its heritage and alive community traditions. Hereby, the government can learn from other mature tourism destinations to avoid mistakes that have been made in this field already.

Finally, the management of the WHSs is the executive authority on location. The results of the study have made clear that visitors missed informative interpretation of the heritage site that was visited. The review of literature has shown that heritage tourists are eager to learn, and this wish should be fulfilled through information panels, brochures, guides and other tools of education. Another characteristic of heritage tourists that has become evident is the willingness to spend money during the visit. Silberberg described this phenomenon already in 1995 and in the Omani case, visitors' satisfaction increased with higher spending and possibilities to buy food, beverages and souvenirs. These opportunities were often either missed or perceived as improvable. This is a chance that should be used by the government since providing information and spending opportunities would mean an increase not only in revenue but also visitor satisfaction which heavily depends on attributes beyond culture and heritage as results have shown.

\section{Limitations and Future Research}

Naturally, the presented study implicates limitations. First, it makes a static analysis, in the sense that it was conducted over a certain period of time. Therefore, only an excerpt of visitor opinions can be shown and results might have been different at another point of time. Also, questionnaires have only been handed out in English (and German in Land of Frankincense) which excluded visitors who are not able to speak either language.

For future work on this topic it would be interesting to conduct similar studies during other periods of the year and compare the results to identify whether the findings of this study are representative for visitors throughout the entire year or only show specific opinions. Longitudinal studies would provide the most well-grounded and useful results and give information on the dynamics of World Heritage visitor demographics, travel patterns and attribute satisfaction. Especially when the level of interpretation and facilities has been improved, a new satisfaction study that compares results to the one at-hand could provide evidence for the assumption that satisfaction significantly increases.

\section{References}

- Adie, B. A., Hall, C. M. (2016). Who visits World Heritage? A comparative analysis of three cultural sites. Journal of Heritage Tourism, 12(1), 67-80.

- Altunel, M. C., Erkut, B. (2015). Cultural tourism in Istanbul: The mediation effect of tourist experience and satisfaction on the 
relationship between involvement and recommendation intention. Journal of Destination Marketing \& Management, 4(4), 213-221.

- Apostolakis, A., Jaffry, S. (2005). A choice modeling application for Greek heritage attractions. Journal of Travel Research, 43(3), 309-318.

- Atkins. (n.D.). Bahla Fort and Oasis World Heritage Site. Retrieved from http://www.atkinsglobal.com/en$\mathrm{gb} /$ projects/bahla-fort-and-oasis-worldheritage-site

- Babakus, E., Boller, W. G. (1992). An Empirical Assessment of the Servqual Scale. Journal of Business Research 24(3), 253-268.

- Baker, D. A., Crompton, J. L. (2000). Quality, satisfaction and behavioral intentions. Annals of Tourism Research, 27(3), 785-804.

- Bianchi, R. V. (2002). The Contested Landscape of World Heritage on a Tourist Island: The Case of Garajonay National Park, La Gomera. International Journal of Heritage Studies, 8(2), 81-97.

- Bowes, R.G. (1989). Tourism and heritage: a new approach to the product. Recreation Research Review, 14(4), 35-40.

- Chen, C., Chen, F. (2010). Experience quality, perceived value, satisfaction and behavioral intentions for heritage tourists. Tourism Management, 31(1), 29-35.

- Chen, J. S. (1998). Travel Motivation of Heritage Tourists. Tourism Analysis, 2(3-4): 213-15.

- Chi, C.G.-Q., Qu, H. (2008). Examining the structural relationship of destination image, tourist satisfaction and destination loyalty: an integrated approach, Tourism

Management, 29(4), 624-636.

- Chon, K.-S., Olson, M. D. (1991) Functional and symbolic congruity approaches to consumer satisfaction/dissatisfaction in consumerism. Journal of the International Academy of Hospitality Research, 1, 2-23.

- Churchill, G. R., Surprenant, C. (1982). An Investigation into Determinants of Customer Satisfaction. Journal of Marketing Research 19, 491-504.

- Dabholkar, P. A., Shepherd, C. D., Thorpe, D. I. (2000). A comprehensive framework for service quality: An investigation of critical conceptual and measurement issues through a longitudinal study. Journal of Retailing, 76(2), 139-173.

- De Rojas, C., Camarero, C. (2008). Visitors' Experience, Mood and Satisfaction in a Heritage Context: Evidence from an Interpretation Center. Tourism Management, 29(3), 525-37.

- Dorfman, P. W. (1979). Measurement and Meaning of Recreation Satisfaction: A Case Study in Camping. Environment and Behavior, 11(4), 483-510.

- Garrod, B., Fyall, A. (2000). Managing heritage tourism. Annals of Tourism Research, 27(3), 682-708.

- Graham, B., Ashworth, G. J., Turnbridge, J. E. (2000). A Geography of Heritage: Power, Culture and Economy. London: Arnold.

- Hall, C. M., Piggin, R. (2003). WHSs: Managing the brand. In A. Fyall, B. Garrod, \& A. Leask (Eds.), Managing visitor attractions: New directions (pp. 203219). Oxford: Butterworth Heinemann.

- Huh, J., Uysal, M., McCleary, K. (2006). Cultural / Heritage Destinations: Tourist Satisfaction and Market Segmentation. Journal of Hospitality \& Leisure Marketing, 14(3), 81-99.

- Johanson, L. B., Olsen, K. (2010). Alta museum as a tourist attraction: The importance of location. Journal of Heritage Tourism, 5(1), 1-16.

- Jusoh, J., Masron, T., Hamid, N. F. A., \& Shahrin, N. (2013). Tourist Expectation and Satisfaction towards Physical Infrastructure and Heritage Elements in Melaka UNESCO World Heritage Site. Academic Journal of Interdisciplinary Studies, 2(8), 733-739.

- Kao, Y.-F., Huang, L.-S., Wu, C.-H. (2008). Effects of theatrical elements on experiential quality and loyalty intentions for theme parks. Asia Pacific Journal of Tourism Research, 13(2), 163-174.

- Kerstetter, D. L., Confer, J. J., Graefe, A. R. (2001). An exploration of the specialization concept within the context of heritage tourism. Journal of Travel Research, 39, 267274.

- King, L. M., Prideaux, B. (2010). Special interest tourists collecting places and destinations: A case study of Australian WHSs. Journal of Vacation Marketing, 16(3), 235247. 
- Kozak, M., Rimmington, M. (2000). Tourist Satisfaction with Mallorca, Spain, as an OffSeason Holiday Destination. Journal of Travel Research, 38(3), 260-269.

- Marcotte, P., Bourdeau, L. (2006). Tourists' Knowledge of the UNESCO Designation of WHSs: The Case of Visitors to Quebec City. International Journal of Arts Management, 8(2), 4-13.

- McKercher, B. (2002). Towards a classification of cultural tourists. International Journal of Tourism Research, 4, 29-38.

- McKercher, B., Ho, P. S.Y., du Cros, H. (2005). Relationship between tourism and cultural heritage management: Evidence from Hong Kong. Tourism Management, 26(4), 539-548.

- Meng, F., Tepanon, Y., Uysal, M. (2008). Measuring tourist satisfaction by attribute and motivation: The case of a nature-based resort. Journal of Vacation Marketing, 14(1), 41-56.

- OECD. (2009). The impact of culture on tourism. Paris: Author

- Oliver, Richard L. (1980). A Cognitive Model of the Antecedents and Consequences of Satisfaction Decisions. Journal of Marketing Research, 17(November), 460-69.

- Otto, J. E., Ritchie, J. R. B. (1996). The service experience in tourism. Tourism Management, 17(3), 165-174.

- Palau-Saumell, R., Forgas-Coll, S., SánchezGarcía, J., Prats-Planagumà, L. (2013). Tourist Behavior Intentions and the Moderator Effect of Knowledge of UNESCO WHSs: The Case of La Sagrada Família. Journal of Travel Research, 52(3), 364-376.

- $\quad$ Pavesi, A., Gartner, W. C., Denizci Guillet, B. (2016). The Effects of a Negative Travel Experience on Tourists' Decisional Behavior. International Journal of Tourism Research, 18(5), 423-433.

- Pearce, P. L. (1982). Perceived Changes in Holiday Destinations. Annals of Tourism Research, 9, 145-164.

- Pizam, A., Milman, A. (1993). Predicting Satisfaction Among First Time Visitors to a Destination by Using the Expectancy Disconfirmation Theory. International Journal of Hospitality Management, 12, 197-209.

- $\quad$ Pizam, A., Neumann, Y., Reichel, A. (1978). Dimentions of tourist satisfaction with destination area. Annals of Tourism Research, 5(3), 314-322.

- Poria, Y., Butler, R., Airey, D. (2003). The Core of Heritage Tourism. Annals of Tourism Research, 30(1), 238-54.

- Poria, Y., Reichel, A., Cohen, R. (2013). Tourists' perceptions of World HeritageSite and its designation. Tourism Management, 35, 272-274

- Prentice, R.C. (1993) Tourism and Heritage Attractions. London: Routledge

- $\quad$ Ramires, A., Brandão, F., Sousa, A. C. (2016). Motivation-based cluster analysis of international tourists visiting a World Heritage City: The case of Porto, Portugal. Journal of Destination Marketing and Management, (May), 1-12.

- Remoaldo, P. C., Ribeiro, J. C., Vareiro, L., Santos, J. F. (2014). Tourists' perceptions of world heritage destinations: The case of Guimaraes (Portugal). Tourism and Hospitality Research, 14(4), 206-218.

- Richards, G. (1996). Production and Consumption of European Cultural Tourism. Annals of Tourism Research, 23(2), 261-283

- Richards, G. (1997). The social context of cultural tourism. In: Richards G. (ed.) Cultural Tourism in Europe. Wallingford: CAB International

- $\quad$ Ritchie B., Inkari, M. (2006) Host community attitudes toward tourism and cultural tourism development: the case of the Lewes District, Southern England. International Journal of Tourism Research, 8(1), 27-44.

- $\quad$ Rust, R. T., Zahorik, A. J., Keiningham, T. L. (1996). Service Marketing. New York: HarperCollins.

- Shackley, M. (Ed.). (1998). Visitor management: Case studies from World Heritage Sites. (pp. 46-65). Oxford: Butterworth-Heinemann.

- Smith, S. L. J. (1988). Defining tourism: a supply-side view. Annals of Tourism Research, 18, 312-318.

- Teas, R.K. (1994). Expectations as a Comparison Standard in Measuring Service Quality: An Assessment of a Reassessment, Journal of Marketing 58(1), 132- 139.

- Timothy, D. J. (2011). Cultural heritage and tourism: An introduction. Bristol: Channel View Publications. 
- Timothy, D. J., Nyaupane, G. P. (2009). Heritage tourism in the developing world: Reflections and ramifications. In Cultural Heritage and Tourism in the Developing World: Routledge.

- Timothy, D.J., Boyd, S.W. (2003). Heritage tourism. Harlow, England, New York: Pearson Education

- Trinh, T. T., Ryan, C. (2013). Museums, exhibits and visitor satisfaction: a study of the Cham Museum, Danang, Vietnam. Journal of Tourism and Cultural Change, 11(4), 239-263.

- Tse, D. K., Wilton, P. C. (1988). Models of consumer satisfaction formation: an extension. Journal of Marketing, 25(May), 204-212

- UNESCO. (1972). Convention Concerning the Protection of the World Cultural and Natural Heritage. General Conference Seventeenth Session, 1(November), 135-145.

- UNESCO. (n.D.-a). World Heritage List Nominations.Retrievedfrom:http://whc.unesco. org/en/nominations/

- UNESCO. (n.D.-b). Land of Frankincense. Retrieved from:http://whc.unesco.org/en/list/10

- UNWTO, \& ETC (2005). City tourism and culture: The European experience Madrid: World Tourism Organisation and European Travel Commission.

- Wang, Z., Yang, Z., Wall, G., Xu, X., Han, F., Du, X., Liu, Q. (2015). Is it better for a tourist destination to be a world heritage site? Visitors' perspectives on the inscription of Kanas on the World Heritage List in China. Journal for Nature Conservation, 23, 19-26.

- Weaver, P., Kaufman, T. J., Yoon, Y. (2001). A market segmentation study based on benefits sought by visitors at heritage sites. Tourism Analysis, 6(3-4), 213- 222.

- Wigle, R. (1994). Making history seem tempting: marketing an historic site as a visitor attraction. Journal of Travel and Tourism Marketing, 3(2), 95-101.

- Williams, K. (2005). The Meaning and Effectiveness of World Heritage Designation in the USA. in: The Politics of World Heritage: Negotiating Tourism and Conservation, edited by D. Harrison and M. Hitchcock. Clevedon, UK: Channel View, pp. 132-36.

- Yan, Ch., Morrison, A. M. (2007). The Influence of Visitors' Awareness of World Heritage Listings: A Case Study of Huang- shan, Xidi, and Hongcun in Southern Anhui, China. Journal of Heritage Tourism, 2(3), 184-95.

- Yang, C. H., Lin, H. L., Han, C. C. (2010). Analysis of international tourist arrivals in China: The role of WHSs. Tourism Management, 31(6), 827-837.

- $\quad$ Yang, C. H., Lin, H. Y. (2014). Revisiting the relationship between World Heritage Sites and tourism. Tourism Economics, 20(1), 73-86.

- Yankholmes, A. K. B., Akyeampong, O. A. (2010). Tourists' perceptions of heritage tourism development in Danish-Osu, Ghana. International Journal of Tourism Research, 12, 603-616

- Yoon, Y., Uysal, M. (2005). An Examination of the Effects of Motivation and Satisfaction on Destination Loyalty: A Structural Model. Tourism Management 26, 45-56.

- Zhang, C., Fyall, A., Zheng, Y. (2014). Heritage and tourism conflict within world heritage sites in China: a longitudinal study. Current Issues in Tourism, 18(July 2014), 127. 